\title{
アレルギー性結膜炎における冷却シートの効果と淚液中ヒスタミン濃度
}

\author{
平川宣幸, ${ }^{*, a}$ 矢ノ下良平, ${ }^{b}$ 吉井 大, $^{c}$ 矢野博子 $a$
}

\section{Relation between Cooling Sheet Effect and Tear Histamine Concenration in Allergic Conjunctivitis}

\author{
Nobuyuki Hirakawa, ${ }^{* a}{ }^{a}$ Ryohei YANOSHItA, ${ }^{b}$ Masaru YoshiI, ${ }^{c}$ and Hiroko YANO ${ }^{a}$ \\ ${ }^{a}$ Kobayashi Pharmaceutical Co., Ltd., 30-3, 1-Chome, Toyokawa, Ibaraki, Osaka 567-0057, Japan, \\ ${ }^{b}$ Faculty of Pharmaceutical Sciences, Hoshi University, 4-41, 2-Chome, Ebara, Shinagawa-ku, \\ Tokyo 142-8501, Japan, and 'Kamifukuoka Ekimae Eyeclinic, 4-5, 6-Chome, \\ Kamihukuoka, Fujimino, Saitama 356-0004, Japan
}

(Received January 6, 2010; Accepted March 9, 2010)

\begin{abstract}
Six allergic conjunctivitis patients (12 eyes) and 4 healthy volunteers ( 8 eyes) were investigated in terms of the effect of cooling sheets on eye itching and tear histamine concentration, before and $5 \mathrm{~min}$ after cooling the eyelids with cooling sheets. The severity of itching was evaluated with a five-level itching score. The combination treatment of levocabastine with cooling sheets significantly reduced eye itching, while no significant change in tear histamine concentration was observed before and after cooling sheet use. The cooling sheets are useful for reducing eye itching in the therapy of allergic conjunctivitis. The tear histamine concentration did not correlate with the antiitching effect of cooling sheets in this study.
\end{abstract}

Key words_—allergic conjunctivitis; cooling sheet; itching; tear histamine

\section{緒言}

アレルギー性結膜炎における瘙痒感に対して，ヒ スタミン $\mathrm{H}_{1}$ 拮抗剤点眼薬を始めとする薬物療法の 有用性が報告されている.1)しかし，いったん疼㾕 感が生じた場合, 薬物療法だけでは櫁痒感の改善に 対処できない場合が多く，瘙痒感を抑えるために患 者は眼を擦る動作を行う。眼を擦ると，その痛みの 刺激によって櫁痒感が抑制される，痛みの刺激が， 痛みの末梢神経である $\mathrm{C}$ 神経や $\mathrm{A} \delta$ 神経を介し て，かゆみの $\mathrm{C}$ 神経を抑制するためと考えられて いる. ${ }^{2)}$ かゆい部分を擦る行為は，一時的に痛み神 経を活動させて瘙痒感を抑えるが，擦ることにより さらに瘙痒感が増強するため, 眼瞼炎や角膜障害を 起こす可能性が高くなる。眼を擦り過ぎたために症 状を悪化させて，外来を受診する患者が後を絶たな い.しかし，瘙痒感が生じてしまった時の対処法を 適切に指導している臨床医は, 非常に少ない. ${ }^{3)}$

$a$ 小林製薬株式会社日用品事業部開発部， $b$ 星薬科大学 生物学研究室, $c$ 上福岡駅前アイクリニック

*e-mail: no.hirakawa@kobayashi.co.jp
冷刺激によっても櫁痒感が抑制されることが知ら れている. ${ }^{2}$ 痛みの刺激と同様に，冷覚伝達神経の 活動が脊髄レベルでかゆみの神経を抑制するためと 考えられている. しかし，冷却は臨床においてはか ならずしも積極的に治療に用いられていない．吉井 ら4) は，冷却シートを眼周囲に貼付して眼瞼部皮膚 を冷却する方法を考案し，アレルギー性結膜炎症の 㿑痒感を即効的に抑制するのに有効であることを報 告した。ヒスタミンはかゆみ神経である $\mathrm{C}$ 神経を 刺激して，瘙痒感が中枢に伝達される，冷覚伝達神 経の活動は脊髄レベルでかゆ夕神経の活動を抑制す ると考えられている. ${ }^{2}$ 一方，冷却によって肥満細 胞の活性化が抑制されヒスタミン遊離が低下する可 能性も考えられるが，この点については全く調べら れていない，そこで，アレルギー性結膜炎の涙液中 のヒスタミン濃度を測定して検討した。 今回, 冷却 シートを下眼瞼周囲に貼付する前後に, 涙液中のヒ スタミン濃度を測定し，眼瘙痒感との関連性につい て臨床的に検討した。また，アレルギー性結膜炎の 治療によく使用されている抗ヒスタミン薬であるレ ボカバスチン点眼投与と冷却シートの併用効果につ 
いても検討した.

\section{方法}

1. 対象者 対象者はスギ花粉症の既往を有す るアレルギー性結膜炎症例 6 例 12 眼で, インフ オームドコンセントのもとに問診と検査を実施し た。対象症例は, 細隙灯顕微鏡下に上眼瞼を翻転し て結膜の乳頭増殖や赤点の存在を確認し，表層角膜 炎を認めない症例とした。埼玉県坂戸市のスギ花粉 飛散情報（キッセイ薬品ホームページ http://www. kissei.co.jp）を参考にして，スギ花粉が飛散してい る 2008 年 3 月 1 日-3 月 25 日に研究を実施した。 アレルギー性結膜炎症例 6 例 12 眼のうち，冷却 シートのみ使用は 3 例 6 眼, 冷却シートとレボカバ スチン点眼併用は 3 例 6 眼であった。健常者 4 例 8 眼をコントロールとした.

\section{2. 冷却シートによる瘙痒感の判定 Figure 1} (A)に示すような形状に加工した冷却シートを使用 した. 冷却シートの主成分は，ゲル化剂（ポリアク リル酸ナトリウム)， $0.01 \%$ メンール，多価アル コールで「無添加熱さまシート」 ${ }^{\circledR}$ (小林製薬株式会 社製）に準拠して作成した。冷却シートを下眼瞼に 上から軽く押し当てるようにして貼りつけ，5分間 貼付した [Fig. 1(B)]。吉井ら4)の検討では，一部

(A)

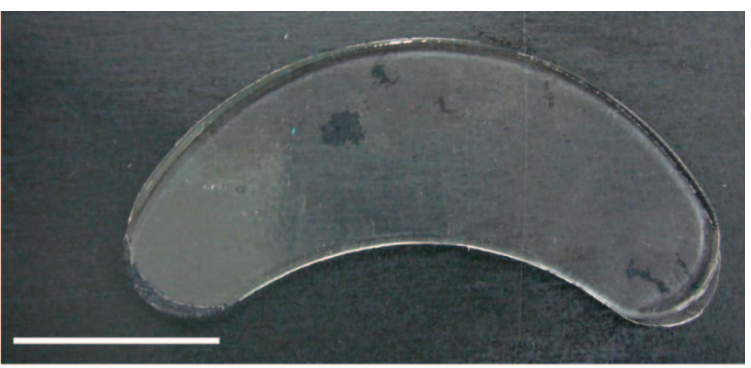

(B)

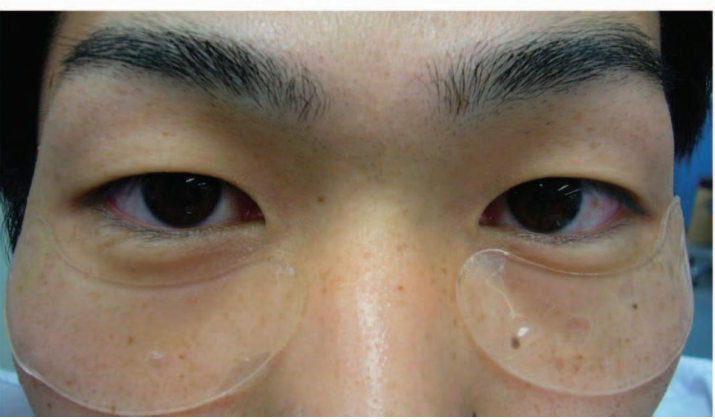

Fig. 1. Cooling Sheet and the Attachment on Eyelid

(A) feature of a cooling sheet. Scale bar, $20 \mathrm{~mm}$. (B) cooling sheets were attached on the lower eyelids.
の症例で上眼瞼への貼付が困難であつたため, 本研 究では前回よりも大きいサイズのシートを下眼瞼へ のみ貼付した．貼付が終了して 5 分後に，問診によ つて，櫁痒感の程度を 5 段階 $(1:$ 全く何も感じな い，2：微妙になにか痒みらしいものを感じる， 3 : 軽い痒みを感じる，4：強い痒みを感じる，5：我慢 できないほどの痒みを感じる）にスコア化して判定 した。また，スコア 3 以下を軽症例，4 以上を重症 例とした。ヒスタミン $\mathrm{H}_{1}$ 拮抗剤点眼薬「レボカバ スチン」と冷却シートの併用については，レボカバ スチン点眼薬を 1 日 4 回, 両眼に 1 週間点眼し, 試 験日に瘙痒感を訴えた患者だけを被験者とした。冷 却シートによる処置はレボカバスチンによる点眼か ら 30 分間経ってから, 上記の手順にて冷却シート を貼付して評価した。 Wilcoxon の符号付順位和検 定で有意差の検定を行った。

\section{3. 涙液中のヒスタミン濃度の測定Uchio} ら5)の方法に従って，シルマー試験紙「STAN-

\section{DARDIZED SCHIRMER TEAR TEST STRIPS}

（日本アルコン侏製）を用いてシルマー第 1 法に準 じて涙液を採取した。採取量は $10 \mu \mathrm{l}(1 \mathrm{~cm})$ とし た。涙液採取は，冷却シート使用前と 5 分間の貼付 後に行つた. 採取後のシルマー試験紙を生理食塩水 （大塚製薬侏製） $200 \mu \mathrm{l}$ に懸濁し，ヒスタミン濃度 測定時まで凍結保存した。涙液中のヒスタミン濃度 は，ヒスタミン ELISA キット「イムノテック」 (秼医学生物学研究所製) を用いて測定した。

結果

アレルギー性疾患を持たない健常被検者の涙液中 ヒスタミン濃度は $2.7 \pm 2.4 \mathrm{ng} / \mathrm{ml} \quad(n=8) \quad$ [Fig. 2 (C) ] であった。 また, 眼痋痒感が生じていない花 粉飛来前の時期に測定したアレルギー性結膜炎患者 の涙液中ヒスタミン濃度は $3.2 \pm 1.6 \mathrm{ng} / \mathrm{ml}$ であっ た.

アレルギー性結膜炎患者に冷却シートのみを使用 した場合，使用後の瘙痒感は，使用前と比較してス コアがおよそ 1 低下して改善傾向がみられたが，有 意差はなかった [Fig. 3(A)]，その時における冷却 シート使用前後の涙液中ヒスタミン濃度はそれぞれ $2.5 \pm 1.0 \mathrm{ng} / \mathrm{ml}, 5.7 \pm 6.0 \mathrm{ng} / \mathrm{ml}$ で, 使用後に約 2 倍に増加したが，有意差は認められなかった $[$ Fig. $2(\mathrm{~A})]$. 


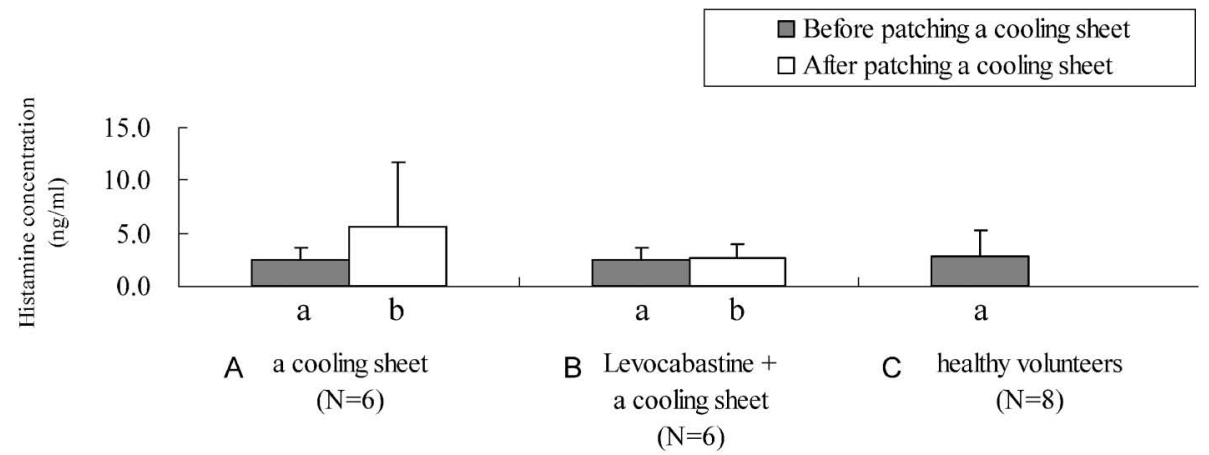

Fig. 2. Tear Histamine Concentration before and after Attaching a Cooling Sheet

(A) a cooling sheet only, (B) combined therapy with levocabastine, allergic conjunctivitis patients; and (C) healthy volunteers.

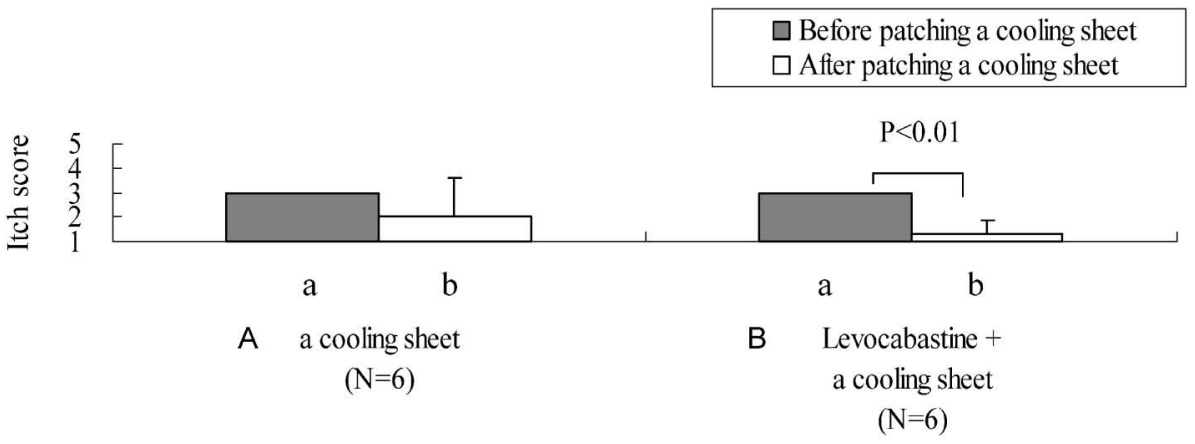

Fig. 3. Itching Score before and after Attaching a Cooling Sheet

(A) a cooling sheet only, (B) combined therapy with levocabastine, in allergic conjunctivitis patients.

レボカバスチンを 1 週間連続点眼投与しても症痒 感がある被験者に対して冷却シートを使用したとこ ろ，ほとんど瘙痒感を感じない程度までに有意に瘙 痒感を抑制した [Fig. 3(B)］が，涙液中ヒスタミ ン濃度は，冷却シートの使用前後で変化はなかった [Fig. 2(B)].

今回の冷却シートの使用対象となつた症例におい て，冷却シート使用の経過中，眼瞼部皮膚に湿疹や 発赤を認めた症例は存在しなかった。細隙灯顕微鏡 検査において，前眼部・中間透光体及び眼底に異常 所見を認めなかった。また，冷却シート使用前後 で, 結膜充血や浮腫について有意な変化は認められ なかった。

\section{考察}

アレルギー性疾患では，マスト細胞が IgE 依存 型アレルギー反応において中心的な役割を演じてい ると考えられている。ヒスタミンは活性化マス卜細 胞から放出されるメディエーターの 1 つであり，好 酸球・好中球の遊走作用，血管内皮細胞への白血球
の接着，血管内皮細胞におけるサイトカインの産 生，線維芽細胞の増殖とコラーゲン産生の促進，毛 細血管透過性立進，分泌充進及び発痛作用の生物活 性を有する。 ${ }^{6}$ また，ヒスタミンは強い起痒作用を 示し，花粉症などのアレルギ一性疾患では，抗ヒス タミン薬が瘙痒感の治療薬として使用されている. しかし，アレルギー性結膜炎で癄痒感が強い時に, 眼を擦って眼障害を引き起こす症例を臨床現場では しばしば経験する。このような場合，抗ヒスタミン 薬を点眼しても即座に薬効が発現しないので，即効 性のある処置が望まれているが，有効な手段がない のが現状である，以前より，冷却が瘙痒感を抑制す ることが知られており，アトピー性皮膚炎など皮膚 科領域で研究が進められている。しかし，眼科領域 のアレルギー性疾患の瘙痒感についてはほとんど調 ベられていない。今回，アレルギー性結膜炎におい て，冷却法が痋痒感抑制に有効であるかを臨床的に 調べた。

今回の研究で得られた健常者及び花粉症患者の涙 液中ヒスタミン濃度は，過去の報告7) とほぼ同等な 
数值であった. また, 花粉飛来のない時期に花粉症 患者の涙液中ヒスタミン濃度測定を行ったところ $3.2 \pm 1.6 \mathrm{ng} / \mathrm{ml}$ で, 花粉症発症時期の濃度（2.5 $1.0 \mathrm{ng} / \mathrm{ml})$ と同程度であった。したがって，花粉 症患者の涙液中ヒスタミン濃度は, 花粉が飛散して いない時期や健常者と比べて，有意な増加は認めら れなかった. 今回の被験者のように軽度から中程度 のかゆみを訴える患者では, ヒスタミン濃度の有意 な増加は観察されないようである。 Leonard ら8) は，アレルギー患者にアレルゲンを眼に投与して惹 起した急性期のアレルギー反応においてヒスタミン は一過性に上昇するが, その後, 低下することを報 告しており, 今回の結果と矛盾しない. 本研究では 被験者のヒスタミン遊離量は健常者と同程度であつ たため, 冷却のヒスタミン遊離に対する影響につい ては, 明確な結論が得られなかった。 今後, アレル ゲン暴露の条件下でヒスタミン濃度の変動を調べる 必要があると考えられる. 最近, ヒスタミン $\mathrm{H}_{4}$ 受 容体, トロンボキサン $\mathrm{A}_{2}$ さらに IL-2 や IL-31 など のサイトカインも瘙痒感に関与していることが報告 されている. ${ }^{9)}$ 今後, ヒスタミン以外のケミカルメ ディエーターについても検討する必要がある.

レボカバスチンは花粉症のようなアレルギー性結 膜炎とアレルギー性鼻炎に処方される抗ヒスタミン 薬である，アレルギ一性結膜炎患者において, 瘙痒 感, 結膜充血, 浮腫が改善されることが報告されて いる. ${ }^{10)}$ また，モルモット及びラットのアレルギー 性結膜炎モデルにおいてヒスタミン及び抗原誘発に よる結膜炎症状（充血及び浮腫）, 結膜の血管透過 性立進を抑制することが報告されている. ${ }^{11)}$ ヒス夕 ミンはアトピー性皮膚炎の瘙痒感には関与が低いと いう報告もあるが, ${ }^{12)}$ 今回抗ヒスタミン薬を点眼し ておいた方が冷却の効果が大きかったことから，ア レルギー性結膜炎では従来報告されているように, ヒスタミンが一定の作用をしていると考えられる.

冷却刺激は, 痛夕刺激と同様に, 冷覚伝達神経の 活動が脊髄レベルでかゆみ神経の活動を抑制すると 考えられている. 冷覚伝達神経の活動には, 冷却刺 激に反応する transient receptor potential melastatine family member 8 (TRPM8) 受容体が重要な役割を 担っている。 TRPM8 受容体は $8-28^{\circ} \mathrm{C}$ の冷却刺激 とメントールにより活性化する受容体で冷感に関与

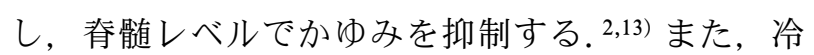

却により皮膚温を低下させることで，かゆみ神経の 閾值を上昇させて癄痒感抑制効果を発揮する. ${ }^{2}$ 温 度が低すぎると，刺激後に血管拡張が強まり，瘙痒 感が増強される。冷却シート貼付によって眼周囲の 温度が約 $4{ }^{\circ} \mathrm{C}$ 下がることから, ${ }^{4)}$ 冷却シートによつ て TRPM8 受容体が活性化したことが考えられ た。本研究では，レボカバスチン処置群の方が，レ ボカバスチン非処置群より冷却の癄痒感抑制効果が 大きかった。アトピー性皮膚炎患者では，ヒスタミ ンに対して過敏になっていることが報告されてい る. ${ }^{14)}$ また，ラットアレルギー結膜炎モデルにおい て，ヒスタミン感受性が充進していることが報告さ れている. ${ }^{15)}$ 今回のアレルギー性結膜炎の被験者で もヒスタミンに対する感受性が充進している可能性 が考えられる。レボカバスチンの 1 週間の処置によ つてかゆみ神経の閾值が上がり，かゆみの感受性が 正常の方へ低下したため, 冷却に対する瘙痒感抑制 効果が大きかったことが考えられるが，さらにメカ ニズムの解明が必要であろう。また, 今回の試験で 実施した症例数は少なかったので, 今後さらに症例 数を増やして詳細に検討していくことが必要である と考えられる.

抗ヒスタミン薬を投与されていても, 癄痒感が発 生し, 眼を擦って症状が悪化する場合が臨床現場で よくみられる.この場合, すぐに抗ヒスタミン薬を 使用しても効果が発現するまで時間を要するので, 即効性のある対症療法が必要であるが, 臨床の現場 では適切な指導がされていないのが現状である. 本 研究は, 冷却がアレルギ一性結膜炎に対して有効な 対症療法であることを示唆している. 今後, 臨床の 現場でも冷却法を薬物療法に併用することによっ て，櫁痒感やそれに伴う眼瞼炎の悪化を防止できる ことが期待できる.

\section{REFERENCES}

1) Ono S. J., Abelson M. B., J. Allergy Clin. Immunol., 115, 118-122 (2005).

2) Ikoma A., “Kayumi Saizensen," eds. by Miyachi Y., Ikoma A., Medical Review Co., Ltd., Tokyo, 2006, pp. 38-41.

3) Ikoma A., "Kayumi Saizensen," eds. by Miyachi Y., Ikoma A., Medical Review Co., Ltd., Tokyo, 2006, pp. 106-109.

4) Yoshii M., Yanashima K., Konishi H., Yano 
H., Rinsho Ganka, 61, 515-517 (2007).

5) Uchio E., Miyakawa K., Ikezawa Z., Ohno S., Br. J. Ophthalmol., 82, 82-87 (1998).

6) Kurosawa M., Morioka J., Inamura H., Suzuki K., Nippon Rinsho, 63, 21-29 (2005).

7) Sakuma Y., Mita H., Allergy, 35, 1158-1162 (1986) .

8) Leonard A. A., Smiyh L. M., Fregona I. A., Salmaso M., Secchi A. G., Eur. J. Ophthalmol., 6, 106-112 (1996).

9) Yosipovitch G., J. Invest. Dermatol., 127, 1857-1859 (2007).

10) Sawa M., Masuda K., Kitano S., Uchida Y.,
Kogure F., Owasawa M., Ogawa N., Atarasi Ganka, 12, 317-332 (1995).

11) Kamei C., Izushi K., Tasaka K., J. Pharmacobio-Dyn., 14, 467-473 (1991).

12) Ikoma A., J. Pharmacol. Sci., 110, 265-269 (2009).

13) Gerhold K. A., Bautista D. M., Ann. N.Y. Acad. Sci., 1170, 184-189 (2009).

14) Ikoma A., Rukwied R., Stander S., Steinhoff M., Miyachi Y., Schmelz M., Arch. Dermatol., 139, 1455-1458 (2003).

15) Minami K., Kamei C., Int. Immunopharmacol., 4, 101-108 (2004). 